https://doi.org/10.3126/batuk.v6i1.32645

THE BATUK : A Peer Reviewed Journal of Interdisciplinary Studies

Vol. 6, Issue No.1, Jan 2020, Page: 72-80

ISSN 2392-4802

\title{
Study of Affecting Factors of Meteorological Parameters on Solar Radiation in Kathmandu Valley
}

\author{
Prakash M. Shrestha ${ }^{1, *}$, Khem N. Poudyal ${ }^{2}$, Narayan P. Chapagain ${ }^{3}$, Indra B. \\ Karki $^{4}$ \\ ${ }^{1}$ Department of Physics, Patan Multiple Campus ,IoST, T. U. \\ ${ }^{2}$ Department of Physics, Pulchowk Engineering Campus, IoE ,T. U. \\ ${ }^{3}$ Department of Physics, Amrit Science Collage, IoST, T.U. Nepal \\ ${ }^{4}$ Nepal Open University, Nepal \\ *Email: pmstha@yahoo.com
}

\begin{abstract}
Solar radiation data are great significance for solar energy systems. This study aimed to estimate monthly and seasonal average daily global solar radiation on a horizontal surface in Kathmandu $\left(27.7^{\circ} \mathrm{N}, 85.5^{\circ} \mathrm{E}, 1350 \mathrm{masl}\right)$, Nepal, by using CMP6 pyranometer in 2012. The influence of the global solar irradiation from different physical as well as meteorological parameters was analyzed. Besides this, the research highlighted that there is high level of fluctuation of the measured value of global solar irradiance due to local weather conditions. As a result of this measurement, the maximum, minimum monthly and yearly mean solar radiation values were $(21.32 \pm 4.14) \mathrm{MJ} / \mathrm{m}^{2} /$ day in May, $(10.93 \pm 2.03) \mathrm{MJ} / \mathrm{m}^{2} /$ day in January and $(16.68 \pm 4.60) \mathrm{MJ} / \mathrm{m}^{2} /$ day found respectively. Annual average of clearness index, maximum temperature, minimum temperature, relative sunshine hour, air mass are $0.51 \pm 0.12,(26.23 \pm 4.96)^{\circ} \mathrm{C},(12.38 \pm 6.83)^{\circ} \mathrm{C}, 0.57 \pm 0.165$ and $1.54 \pm 0.42$ respectively. There is positive correlation of maximum temperature and negative correlation of air mass with global solar radiation.
\end{abstract}

Keywords: Global solar radiation, clearness index, meteorological parameters, air mass, ozone.

\section{Introduction}

Sun is the closest star from the Earth and hence solar energy is the fundamental as well as primary source of governs Earth's climate and atmosphere. Main source of energy of Sun is nuclear fusion. This reaction causes four hydrogen nuclei to fuse together to form one helium nucleus. The helium particle is about 0.7 percent less massive than the four hydrogen nuclei. The released energy is $26.7 \mathrm{MeV}$. The irradiance at the surface of the Sun is $6.3 \times 10^{7} \mathrm{~W} / \mathrm{m}^{2}$ which varies inversely with square of distance as we move away from the Sun. Solar energy has been identified as the largest renewable resources on earth. Solar energy is free energy, clean and free of harmful environmental effects sources. Study of solar radiation and its 
dependence on different meteorological parameters are used agriculture, Hydrology, Climate change.

Nepal is a land-locked south east Asian mountainous country with a large area of beautiful landscape situated between latitudes of $26.36^{\circ} \mathrm{N}$ to $30.45^{\circ} \mathrm{N}$ and longitudes of $80.06^{\circ} \mathrm{E}$ to $88.2^{\circ} \mathrm{E}$. The elevation of the country ranges from $60 \mathrm{~m}$ to $8848 \mathrm{~m}$ within a span of $200 \mathrm{~km}$ from south to north and about $800 \mathrm{~km}$ from east to west [1]. Nepal is situated between two giant industrial countries India and China and their industrial byproduct can directly affect the concentrations and depletion of ozone concentration over Kathmandu Valley. Therefore, detail study of atmospheric concentration is very important. Nepal lies in sunbelt (latitude $15^{\circ}$ to $35^{\circ}$ ). Thus it receives ample solar radiation through the country, which varying from 12.93 $\mathrm{MJ} / \mathrm{m}^{2} /$ day to $22.48 \mathrm{MJ} / \mathrm{m}^{2} /$ day. Annual solar isolation is $3.6-6.2 \mathrm{kWh} / \mathrm{m}^{2} /$ day and sunshine duration is 300 days in Nepal [2]. In fiscal year 2010/011, 425.16 TJ energy is consumed in Nepal in which, tradition fuel is $83.7 \%$, commercial fuel is $15.5 \%$ and renewable energy is $0.8 \%$ [3]. 4,37,614 vehicle register in Nepal in BS 2074/075 [4]. So large foreign currency is spend to import petroleum product.

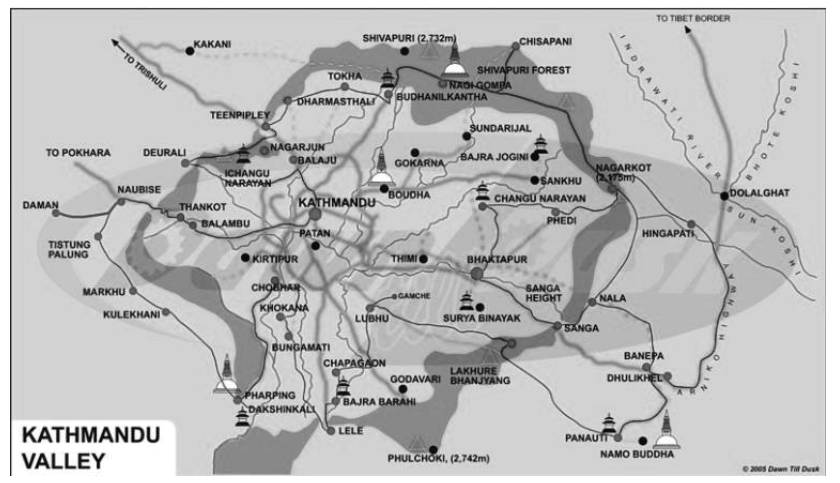

Figure 1. Map of Kathmandu Valley [source:www.lahistoriaconmapas.com/atlas/]

Kathmandu (lat. $27.72^{\circ} \mathrm{N}$, long. $86.37^{\circ} \mathrm{E}$ and alt. $1350 \mathrm{masl}$ ) is capital city of Nepal. Kathmandu valley is combination of Kathmandu district, Lalitpur district and Bhaktapur district covers area 893 sq. km. Kathmandu valley is bowl-shaped. Its central lower part stands at 1,425 masl. Kathmandu valley is surrounded by four mountain ranges: Shivapuriat north, Phulchowki at south, Nagarjun at north west and Chandragiri at west. Population and population density are 2,510,788 and $2793 \mathrm{~km}^{-2}$ respectively [5]. The maximum and minimum GSR of $25.3 \mathrm{MJ} / \mathrm{m}^{2} /$ day and 14.6 MJ/m²/day were observed in May and January respectively. The annual average 
solar energy measuring $5.19 \mathrm{kWh} / \mathrm{m}^{2} /$ day is found in Kathmandu from 2009 to 2010 [6]. The average values attenuation coefficient in Kathmandu during the premonsoon period of 1999 are found to be $0.6027 \pm 0.022$ respectively [7].

\section{Methodology}

The extraterrestrial solar radiation on a horizontal surface $\mathrm{H}_{\mathrm{o}}$ is a function only of latitude and independent of other location parameters. As the solar radiation passes through the earth's atmosphere, it is further modified by processes of scattering and absorption due to the presence of cloud and atmospheric particles. Hence, global solar radiation (GSR) incident on a horizontal surface $\mathrm{H}_{\mathrm{g}}$ is very much locationspecific and less than the extraterrestrial radiation. It is affected by physical and meteorological parameters. It is exponentially attenuated in atmosphere.

According to Bougure-Lembertlaw $[8,9,10]$

$$
H_{g}=H_{o} e^{-K m}
$$

Where

$$
\begin{aligned}
& \quad H_{o}=\frac{24}{\pi} I_{s c}\left[1+0.033 \cos \left(\frac{360}{365} n_{d}\right)\right]\left(\omega_{s} \sin \delta \sin \phi+\cos \delta \cos \phi \sin \omega_{s}\right) \\
& \delta=\text { solar declination }=23.45 \sin \left(\frac{360}{365}\left(284+n_{d}\right)\right) \\
& \mathrm{I}_{\mathrm{sc}}=\text { solar constant }=1367 \mathrm{~W} / \mathrm{m}^{2}[11] \\
& \mathrm{n}_{\mathrm{d}}=\text { no. of day of year }(\mathrm{DOY}) \\
& \phi=\text { latitude } \\
& \omega_{\mathrm{s}}=\text { sunshine hour angle }=\cos ^{-1}(-\tan \delta \tan \phi) \\
& \mathrm{K}=\text { attenuation coefficient }
\end{aligned}
$$

Air mass (m) depends on atmospheric pressure $(\mathrm{P})$, Solar zenith angle $\left(\theta_{\mathrm{z}}\right)$, solar hour angle $(\omega)$, latitude $[12,13]$.

$$
m=\frac{P}{101325} \frac{1}{\left(\cos \theta_{z}+0.15\left(93.885-\theta_{z}\right)^{-1.253}\right)}
$$

Global solar radiation (GSR) and meteorological data are collected from Department of Hydrology and Meteorology (DHM) for year 2012. GSR is measured by CMP6 
first class pyranometer [14] shown in Figure 2. Data of Total ozone content are collected from website http:/data.ceda.ac.uk/badc/toms/data/omi/. The Ozone Monitoring Instrument (OMI) derives its heritage from NASA's Total Ozone Mapping Spectrometer (TOMS) instrument. TOMS is a NASA satellite instrument for measuring ozone values in troposphere. Matlab 2015 software is used to analysis and plot graph.
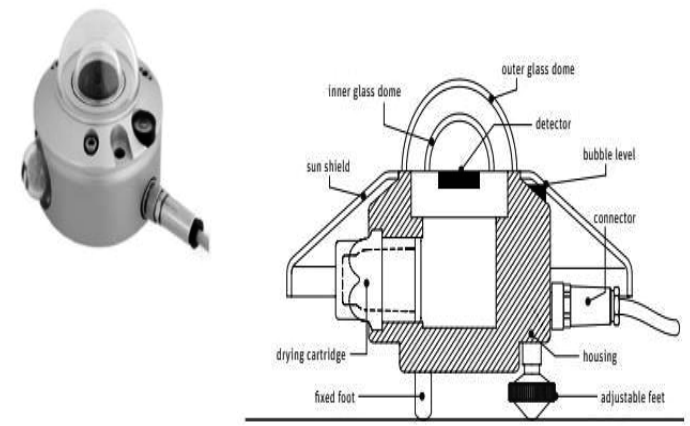

- Thermopile sensor

- GSR (in W/m²)

- Spectral range $=285 \mathrm{~nm}-2800 \mathrm{~nm}$

- Operating temperature $=-40^{\circ} \mathrm{C}-80^{\circ} \mathrm{C}$

- Field of view $=180^{\circ}$

- Sensitivity $=5-20 \mathrm{mV} /\left(\mathrm{Wm}^{2}\right)$

- Response time $<18 \mathrm{sec}$

Figure 2. CMP6 pyranometer [source: www.kippzonen.com]

\section{Results and Discussion}

Figure 3 indicates variation of global solar radiation with day, month and season. GSR is maximum $26.99 \mathrm{MJ} / \mathrm{m}^{2} /$ day in $134^{\text {th }}$ day of year and minimum 3.12 $\mathrm{MJ} / \mathrm{m}^{2} /$ day in $262^{\text {th }}$ day of year respectively. It has maximum value $(21.32 \pm 4.14)$ $\mathrm{MJ} / \mathrm{m}^{2} /$ day in May due to less solar declination and high temperature and is minimum $(10.93 \pm 2.03) \mathrm{MJ} / \mathrm{m}^{2} /$ day in January due to less solar declination and low temperature. It varies large $\left(5.11 \mathrm{MJ} / \mathrm{m}^{2} /\right.$ day) in August and less $\left(1.05 \mathrm{MJ} / \mathrm{m}^{2} /\right.$ day $)$ in December. Its value is maximum $(19.95 \pm 3.91) \mathrm{MJ} / \mathrm{m}^{2} /$ day in Spring and minimum $(13.00 \pm 1.96) \mathrm{MJ} / \mathrm{m}^{2} /$ day in Winter. Variation is maximum $\left(5.02 \mathrm{MJ} / \mathrm{m}^{2} /\right.$ day $)$ in Summer and minimum $\left(1.96 \mathrm{MJ} / \mathrm{m}^{2} /\right.$ day $)$ in Winter. 
$76 \mid$ THE BATUK : A Peer Reviewed Journal of Interdisciplinary Studies

Vol. 6 Issue No.1

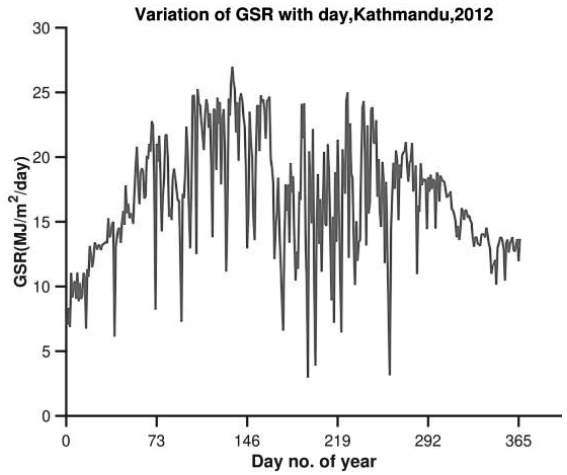

a) Daily

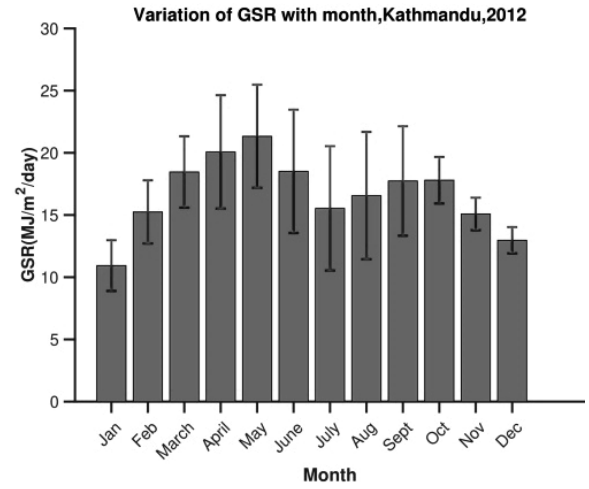

b) Monthly

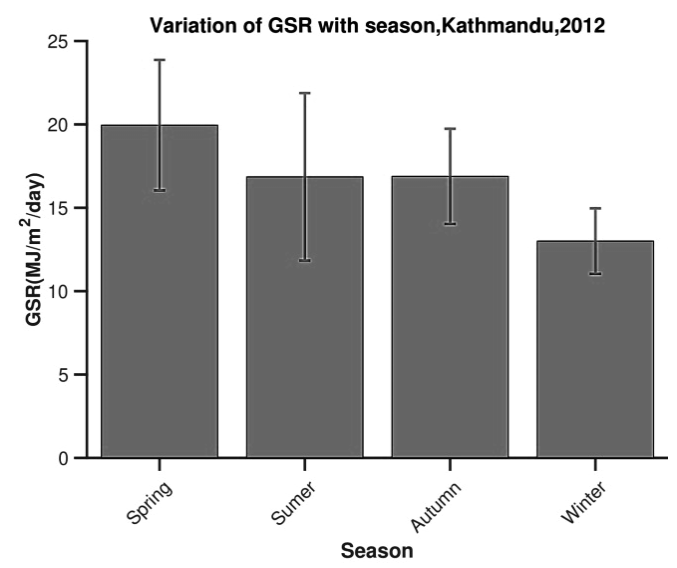

c) Seasonal

Figure 3. Variation of GSR

Figure 4 shows variation of clearness index $\left(\mathrm{K}_{\mathrm{T}}=\mathrm{H}_{\mathrm{g}} / \mathrm{H}_{\mathrm{o}}\right)$ with day number of year (DOY). Clearness index is maximum 0.70 and minimum 0.06 are found in $57^{\text {th }}$ day of year and in $195^{\text {th }}$ day of year respectively. Number of cloudy days $\left(\mathrm{K}_{\mathrm{T}}<0.34\right)$ is 41 and number of clear day $\left(\mathrm{K}_{\mathrm{T}}>0.65\right)$ is 36 . Figure 5 shows variation of attenuation (extinction) coefficient with month. Its maximum value $(0.82 \pm 0.04)$ in July and minimum value $(0.54 \pm 0.04)$ in January. 


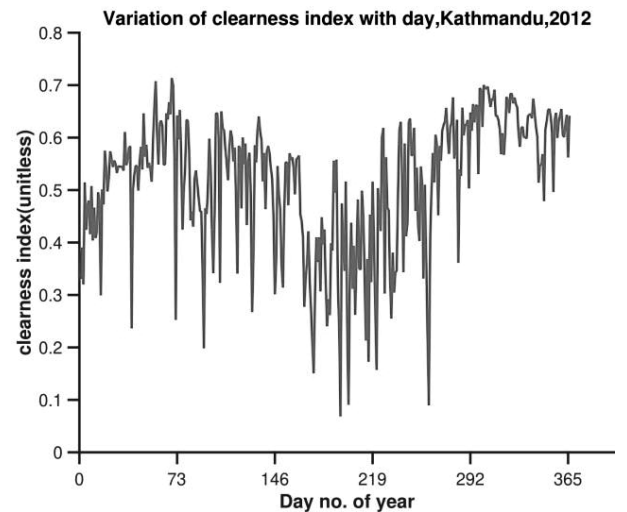

Figure 4. Daily variation of clearness index

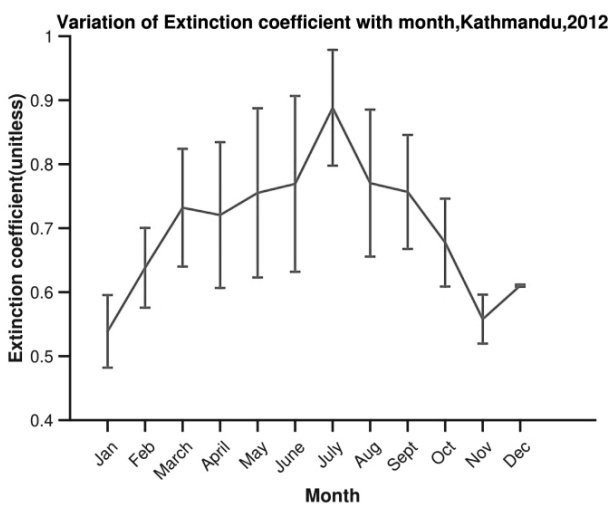

Figure 5. Monthly variation of attenuation coefficient

Temperature of hottest day is $35.2^{\circ} \mathrm{C}$ in $166^{\text {th }}$ day of year that of coldest day is $0^{\circ} \mathrm{C}$ in $15^{\text {th }}$ day of year. Number of rainy days is 121 and total rain fall is $1464.7 \mathrm{~mm}$. Annual mean of maximum and minimum temperature are $(26.23 \pm 4.96)^{\circ} \mathrm{C}$ and $(12.38 \pm 6.83)^{\circ} \mathrm{C}$ respectively. Figure 6 shows variation of GSR with maximum temperature, minimum temperature, rainfall and relative humidity (RH). Correlation coefficient of GSR with those parameters are shown in Table 1. Maximum and minimum temperature effect more on GSR. Negative correlation of relative humidity on GSR. But effect of rainfall on GSR is not significant.

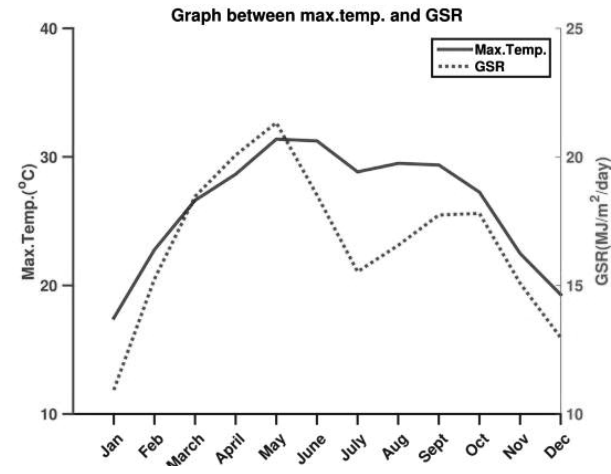

a) Maximum temperature

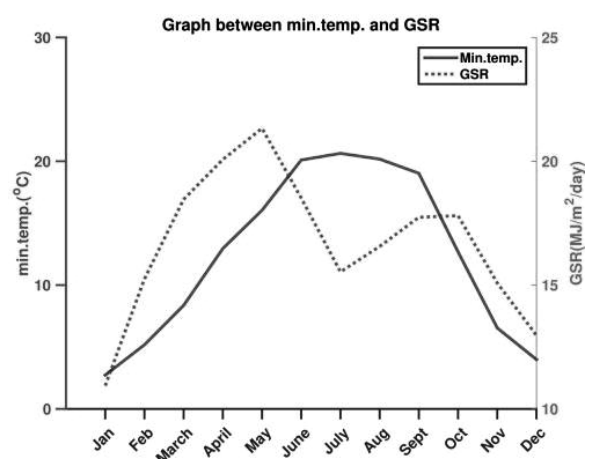

b) Minimum temperature 


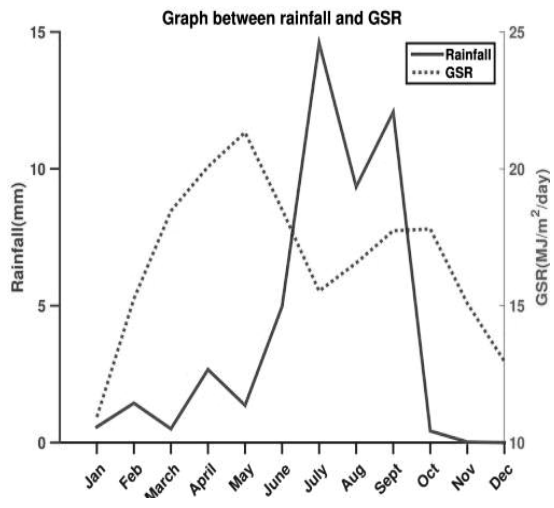

a) Rainfall

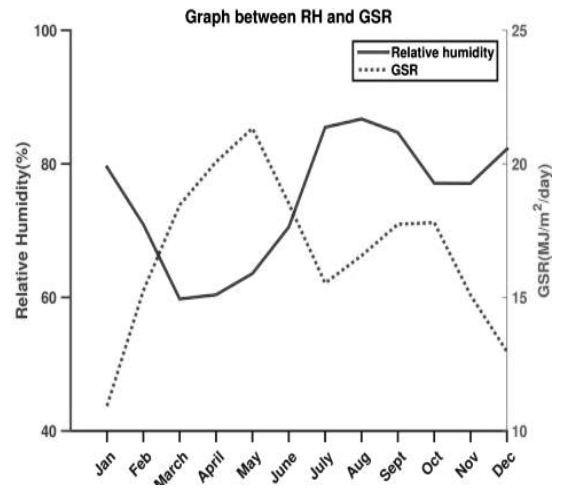

b) Relative humidity

Figure 6. Variation of GSR

Annual mean of relative humidity is $(74.87 \pm 12.60) \%$. The values of precipitable water content $(\mathrm{w})$ in $\mathrm{cm}$. were estimated using Leckner equation using the relative humidity $(\mathrm{RH})$ as a fraction of one and the ambient temperature (T) in Kelvin [15]. $\mathrm{N}$ is day length $\left(=2 \omega_{\mathrm{s}} / 15\right)$ and $\mathrm{n}$ is sunshine hour. Annual mean of relative sunshine hour $(\mathrm{n} / \mathrm{N})$ and air mass are $0.57 \pm 0.16$ and $1.54 \pm 0.42$ respectively. Yearly mean of total ozone column (TOC) is $(251.02 \pm 4.09)$ DU. Figure 7 shows variation of GSR with water content, air mass, relative sunshine hour and TOC. Correlation coefficients of GSR with those parameters are shown in Table 1. Effect of air mass on GSR is negative. But effect of water content, relative sunshine hour and total ozone column on GSR are not significant.

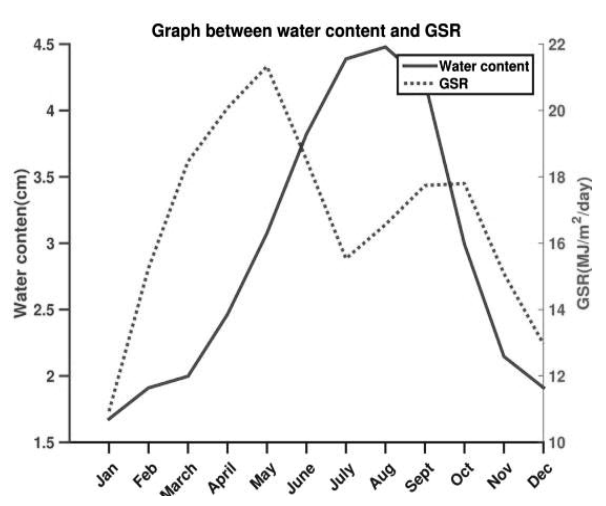

a) Water content

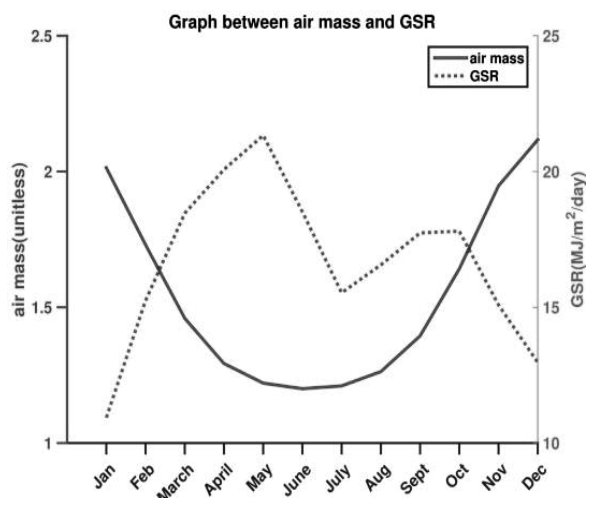

b) Air mass 


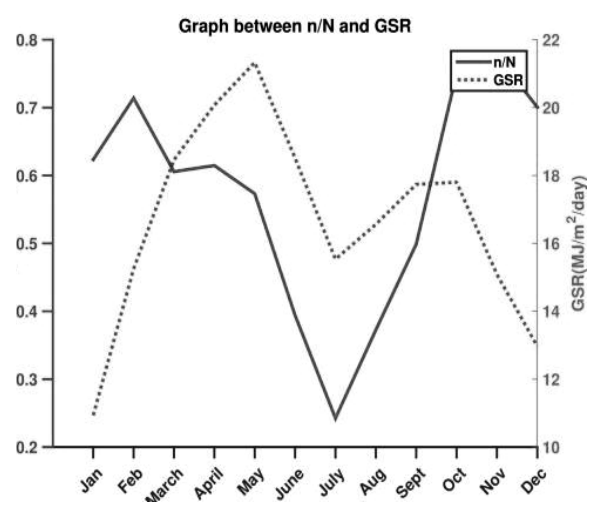

c) Relative sunshine hour

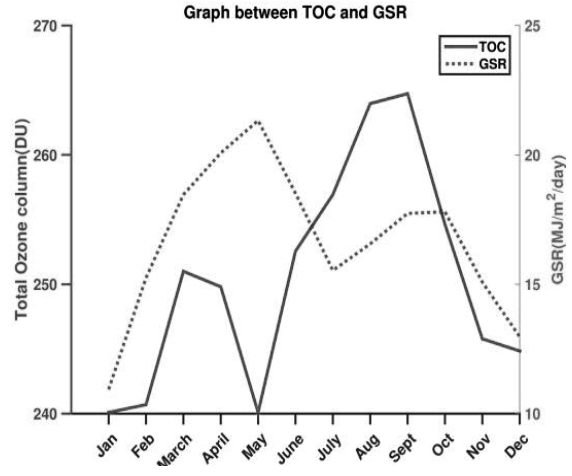

d) Total ozone column

Figure 7. Variation of GSR

Table 1

Relation of GSR with Meteorological Parameters

\begin{tabular}{ll}
\hline Parameters & Correlation coefficient \\
\hline Maximum temperature & 0.65 \\
Minimum temperature & 0.47 \\
Rainfall & 0.09 \\
Relative Humidity & -0.6 \\
Water content & 0.36 \\
Air mass & -0.73 \\
Relative sunshine hour & -0.16 \\
Total ozone column & 0.24 \\
\hline
\end{tabular}

\section{Conclusions}

Annual mean of GSR and clearness index for 2012 in Kathmandu Valley are (16.68 $\pm 4.60) \mathrm{MJ} / \mathrm{m}^{2} /$ day and $0.51 \pm 0.12$ respectively. Yearly mean of attenuation coefficient is $0.24 \pm 0.06$. There is positive correlation of GSR with maximum temperature and negative correlation with air mass. $5.45 \times 10^{6} \mathrm{TJ}$ solar energy incident on Kathmandu Valley in 2012. This energy can used as alternate source of energy. 


\section{References}

[1] Majupuria R K and Majupuria T C, Nepal nature's paradise: insight into diverse facets of topography, flora and ecology, M Devi, Gwalior, India, 1999.

[2] J N Shrestha, T R Bajracharya, S R Shakya, and Bijay Giri. Renewable energy in Nepal progress at a glance from 1998 to 2003, In Proceedings of the International Conference on Renewable Energy Technology for rural Development (RETRUD-03), pages 12-14, 2003.

[3] MoF, Economic Survey 2010/011, Ministry of Finance, Government of Nepal, 2010/011.

[4] DTM, Register vehicles till fiscal year BS 2074/075, BS 2075.

[5] CBS, National population and housing census 2011, 2011.

[6] Khem N Poudyal, Binod K Bhattarai, Balkrishna Sapkota, and Berit Kjeldstad, Solar radiation potential at four sites of Nepal. Journal of the Institute of Engineering, 8 (3): 189-197, 2011.

[7] Balkrishna Sapkota and Rajan Dhaubhadel, Atmospheric turbidity over Kathmandu valley. Atmospheric Environment, 36 (8):1249-1257, 2002.

[8] Muhammad Iqbal, An introduction to solar radiation. New York: Academic Press, 1983.

[9] Kuo-Nan Liou, An introduction to atmospheric radiation, volume 84. Elsevier, 2002.

[10] Murry L Salby, Physics of the Atmosphere and Climate, Cambridge University Press, 2012.

[11] John A Duffie and William A Beckman, Solar engineering of thermal processes. John Wiley \& Sons, 2013.

[12] Lunche Wang, Yisen Chen, Ying Niu, German Ariel Salazar, and Wei Gong, Analysis of atmospheric turbidity in clear skies at wuhan, central china, Journal of Earth Science, 28 (4): 729-738, 2017.

[13] John M Wallace and Peter V Hobbs, Atmospheric science: an introductory survey, Volume 92. Elsevier, 2006.

[14] Kipp and Zonen, Instruction manual CMP6 pyranometer, 2008.

[15] M El-Nouby Adam and Eman F El-Nobi, Correlation between air temperature and Atmospheric turbidity at a subtropical location, World Environment, 7 (1):1-9, 2017. 